\title{
PENGENALAN PERPUSTAKAAN KEPADA ANAK USIA DINI
}

\author{
Lusi Ismail \\ Pustakawan UIN Imam Bonjol Padang \\ e-mail : lusiismail@gmail.com
}

\begin{abstract}
There are many factors behind why Indonesian people do not like literature, so the impact is the lack of interest in reading in Indonesia, especially in rural areas. Introducing the library as a means of information which is an absolute necessity of the community in the information age needs to be done. Awareness of the importance of this library should be fostered since childhood, therefore the thing that needs to be done is to provide adequate facilities / good for children's libraries. But before moving in that direction, the children's soul must be understood and what kind of information is needed by the children. Therefore it is necessary for the active involvement of various parties such as parents, teachers and the government to foster interest in reading early on by introducing the library early on. However, it is difficult to expect children and adolescents to come to the library without any precise effort and resources pull from the library itself. The lack of attention to the elements intended to extend the reading interest of Indonesian people, especially for people in rural areas.
\end{abstract}

Keywords: Library, Early Childhood

\begin{abstract}
Abstrak : Banyak faktor yang melatarbelakangi mengapa masyarakat Indonesia kurang suka ke pustaka, maka dampaknya adalah kurangnya minat baca di Indonesia khusus lagi bagian pedesaan. Memperkenalkan perpustakaan sebagai salah satu sarana informasi yang merupakan kebutuhan mutlak masyarakat dalam era informasi perlu dilakukan. Kesadaran akan pentingnya perpustakaan ini memang sebaiknya dipupuk sejak kecil, oleh karena itu hal yang perlu dilakukan adalah menyediakan fasilitas yang memadai/baik untuk perpustakaan anak-anak. Akan tetapi sebelum melangkah ke arah itu, harus pula dipahami jiwa anak-anak tersebut dan informasi yang seperti apa yang dibutuhkan oleh anak-anak. Oleh karena itu perlu adanya keterlibatan secara aktif dari berbagai pihak seperti orangtua, guru dan pemerintah untuk menumbuhkan minat baca sejak dini dengan memperkenalkan perpustakaan sejak dini.Akan tetapi, sulit mengharapkan anak-anak dan remaja untuk datang ke perpustakaan tanpa ada upaya yang jitu dan daya tarik dari perpustakaan itu sendiri. Kurangnya perhatian elemen-elemen yang dimaksudkan memperpanjang daya minat baca masyarakat Indonesia, khusus bagi masyarakat yang ada di pedesaan.
\end{abstract}

Kata kunci : Perpustakaan, Anak Usia Dini

\section{A. LATAR BELAKANG}

Secara umum perpustakaan mempunyai arti sebagai suatu tempat yang di dalamnya terdapat kegiatan perhimpunan, pengolahan, dan penyebarluasan (pelayanan) segala macam informasi, baik yang tercetak maupun yang terekam dalam berbagai media seperti buku, majalah, surat kabar, film, kaset, tape recorder, video, kumpuer dan lain-lain. Semua koleksi sumber informasi tersebut disusun bedasarkan sistem tertentu dan dipergunakan untuk kepentingan belajar melalui kegiatan membaca dan 
mencari informasi bagi segenap masyarakat yang membutuhkannya. ${ }^{1}$

Ada beberapa jenis
perpustakaan yang tersebar di
masyarakat, misalnya, perpustakaan
sekolah, perpustakaan perguruan tinggi, perpustakaan khusus, dan perpustakaan umum. Jenis perpustakaan tersebut kalau dilihat dari fungsinya adalah sebagai pusat pelayanan masyarakat. Namun apabila diamati lebih lanjut, maka sejenis perpustakaan tersebut bisa terdiri dari berbagai macam perpustakaan lagi yang secara spesifik berfungsi langsung terhadap lembaga yang menaunginya. Misalnya perpustakaan sekolah bernauang di Sekolah Dasar (SD), Sekolah Lanjut Atas Pertama (SLTP), dan Sekolah Umum/Kejuruan (SMU/SMK). Demikian pula untuk jenis perpustakaan Perguruan Tinggi dan Perpustakaan Khusus. Ia berfungsi langsung dengan lembaga induknya.

Sementara itu jenis perpustakaan umum, macamnya cukup bervariasi. Ada perpustakaan umum Kabupaten/Kota Madya, Kecamatan dan perpustakaan Desa. Pengertian umum di sini lebih disifati oleh karakteristik masyarakat penggunaannya yang sangat heterogen, yang meliputi semua batas usia dan semua tingkatannya. Jadi, tidak dibatasi oleh karakteristik sosiodemografinya. ${ }^{2}$

Perpustakaan

sekolah jumlahnya sangat banyak, karena disetiap sekolah, baik ditingkat kanak-

1 Pawit M. Yusuf, Pedoman Penyelenggaraan Perpustakaan Sekolah, (Jakarta, Kencana: 2005), h. 1

${ }^{2}$ Ibid, h. 2 kanak, SD, SLTP dan SMU/SMK, semuanya memiliki perpustakaanya sendiri. Namun, sangat disayangkan perpustakaan yang secara khusus bagi anak usia dini tidak begitu diperhatikan. Apalagi bagi anak usia dini yang berada di pedesaan.

Hal itu tidak terlepas dari penyelenggaraan pelayanan bagi anak usia dini tersebut masih bersifat sektoral, parsial dan belum terintegrasi dengan baik. Beberapa permasalahan yang terjadi di masyarakat berkaitan dengan perpustakaan anak usia dini di antaranya adalah:

1. Minimnya perhatian pemerintah terhadap masyarakat, terutama anak usia dini terkait dengan pengelolan perpustakaan terutama yang ada di lembaga Pendidikan Anak Usia Dini.

2. Masih adanya lembaga Pendidikan Anak Usia Dini (PAUD) yang belum memberikan stimulasi untuk pengenalan perpustakaan terhadap anak usia dini.

3. Kurang tersalurnya bakat-bakat yang harus dikembangkan yang terdapat pada anak usia dini, karena fasilitas penunjang yang mereka masih kurang.

Mengingat permasalahan di atas maka perlu kiranya dipahami tentang pentingnya pengenalan perpustakaan terhadap anak usia dini, agar apa yang dicita-citakan pemerintah bisa tercapai.

Pada makalah ini, penulis akan membahas secara khusus tentang dampak yang ditimbulkan dari pengenalan perpustakaan terhadap 
anak usia dini. Hal ini penting, mengingat karena dalam UndangUndang Nomor 43 tahun 2007 tidak dinyatakan bahwa perpustakaan bagi anak usia dini yang tersebut tidak ada.

Adapun fokus dari tulisan ini adalah :

a. Bagaimana pengenalan perpustakaan terhadap anak usia dini?

b. Apa akibat yang timbul jika kurangnya pengenalan perpustakaan terhadap anak usia dini?

\section{B. PEMBAHASAN}

\section{Pengertian Perpustakaan dan Anak Usia Dini}

Kata perpustakaan berasal dari kata pustaka, yang berarti kitab , bukubuku, kitab primbon. Kemudian kata pustaka mendapat awalan per dan akhiran an, menjadi perpustakaan. Perpustakaan mengandung arti: kumpulan buku-buku bacaan, bibliotek dan hukum-hukum kesusastraan. ${ }^{3}$

Selanjutnya ada istilah "pustakalokal" yang berarti tempat atau ruangan perpustakaan. Pengertian yang lebih umum dan luas dari perpustakaan adalah suatu ruangan, bagian dari gedung/bangunan, atau gedung itu sendiri, yang berisi bukubuku koleksi, yang disusun dan diatur demikian rupa sehingga mudah untuk dicari dan dipergunakan apabila sewaktu-waktu diperlukan oleh pembaca. Perpustakaan dilengkapi dengan berbagai sarana dan prasarana,

\footnotetext{
${ }^{3}$ Kamus Besar Bahasa IndonesiaKBBI, (Jakarta, Kencana: 1988)
}

seperti ruang baca, rak buku, rak majalah, meja kursi, baca kartu-kartu katalog, sistem pengelolaan tertentu dan ditempatkan petugas yang menjalankan perpustakaan agar dapat berjalan sebagaimana semestinya. ${ }^{4}$

\section{Perkembangannya}

menempatkan perpustakaan menjadi sumber informasi ilmu pengetahuan, teknologi dan budaya. Dari istilah pustaka, berkembang istilah pustakawan, kepustakaan, ilmu perpustakaan, dan kepustakawanan yang akan dijelaskan sebagai berikut: ${ }^{5}$

a) Pustaka : Kitab; buku, buku primbon. $^{6}$

b) Pustakawan : Librarian dalam bahasa Indonesia diterjemahkan dengan pustakawan, yaitu seseorang yang bekerja diperpustakaan atau petugas perpustakaan yang mendapat pendidikan ilmu perpustakaan. $^{7}$

Pustakawan adalah orang yang bergerak dibidang perpustakaan, ahli perpustakaan. ${ }^{8}$

Dari pengertian tersebut dapat dikatakan bahwa pustakawan adalah orang yang bekerja, memiliki

4 Sutarno NS, Perpustakaan dan Masyarakat, (Jakarta, Yayasan Obor Indonesia: 2003), h. 7

http://warintek08.wordpress.com/tes/, Diakses pada tanggal 22 Mei 2017

http://kbbi.web.id/pustaka,

Diakses pada tanggal 22 Mei 2017

${ }^{7}$ Agus Rifai, Perpustakaan Islam: Konsep, Sejarah, dan Kontribusinya dalam Membangun Peradaban Islam Masa Klasik, (Jakarta, Rajawali Pers: 2013), h. 6

${ }^{8}$ Kamus Besar Bahasa IndonesiaKBBI, op. cit 
kemampuan, pengalaman, keahlian untuk mengelola dan menyelenggarakan keperpustakaan. ${ }^{9}$

c) Kepustakaan : Bahan-bahan yang menjadi acuan atau bacaaan dalam menghasilkan atau menyusun tulisan baik berupa artikel, karangan, buku, laporan, dan sejenisnya.

d) Ilmu Perpustakaan : Bidang ilmu yang mempelajari dan mengkaji hal-hal yang berkaitan dengan perpustakaan baik dari segi organisasi koleksi, penyebaran dan pelestarian ilmu pengetahuan teknologi dan budaya serta jasajasa lainnya kepada masyarakat, hal lain yang berkenaan dengan jasa perpustakaan dan peranan secara lebih luas.

e) Kepustakawanan : merupakan terjemahan dari bahasa Inggris, yaitu librarianship yang berarti lingkup kerja kepustakaan ${ }^{10}$ atau suatu bidang yang membahas kajian ilmu perpustakaan baik secara teori maupun praktek dan teknologi informasi. Dengan merujuk pada pengertian ini sesungguhnya kepustakawanan merujuk pada tugas-tugas atau kegiatan pustakawanan dalam kaitannya dengan perpustakaan atau kegiatan dalam upaya-upaya pelaksanaan tugas-tugas dan pengembangan perpustakaan. ${ }^{11}$

Perpustakaan bukan merupakan hal yang baru di kalangan masyarakat. Tetapi, walaupun bukan merupakan hal

\footnotetext{
${ }^{9}$ Sutarno NS, op. Cit, h. 8

${ }^{10}$ Kamus Lengkap Bahasa Inggris

${ }^{11}$ Agus Rifai, op.cit, h. 6
}

yang baru, masih banyak orang yang memberikan defenisi yang salah terhadap perpustakaan. Banyak orang yang mengasosiasikan perpustakaan itu dengan buku-buku, sehingga setiap tumpukkan buku pada suatu tempat tertentu disebut perpustakaan. Padahal tidak semua tumpukan buku itu dapat dikatakan perpustakaan. Memang salah satu ciri perpustakaan adalah adanya bahan pustaka atau sering juga disebut koleksi pustaka tetapi masih ada ciriciri lain lebih mengarah kepada arti perpustakaan.

Ada beberapa ciri-ciri perpustakaan yang dapat kita rinci sebagai berikut: ${ }^{12}$

a. Perpustakaan itu merupakan unit kerja

b. Perpustakaan mengelola sejumlah bahan pustaka

c. Perpustakaan harus digunakan oleh pemakai

d. Perpustakan sebagai sumber informasi

Menurut Sujiono, anak usia dini adalah sosok individu yang sedang menjalani suatu proses perkembangan dengan pesat dan fundamental bagi kehiduapan selanjutnya". Pada masa ini anak memerlukan rangsangan stimulus guna mengembangkan segala aspek yang berkaitan dengan perkembangannya. Rangsangan stimulus bisa diperoleh dari

12 Ibrahim Bafadal, Pengelolaan Perpustakaan Sekolah, (Jakarta, Bumi Aksara: 2011), h. 1-3 
orangtua, guru maupun dari masyarakat sekitar anak.

Bagi setiap orang yang mendampingi anak usia dini tersebut, sangat penting untuk memahami bagaimana cara yang tepat dalam mengembangkan setiap aspek perkembangan anak usia dini. Berdasarkan uraian tersebut di atas, dapat dianalisis bahwa anak usia dini adalah sosok individu yang berada pada rentan usia 0-6 tahun yang sedang mengalami proses pertumbuhan yang pesat dan fudamental.

Berdasarkan Permendiknas No. 58 tahun 2009 menyatakan bahwa, tingkat pencapaian perkembangan mengambarkan pertumbuhan dan perkembangan yang diharapkan dicapai anak pada rentang usia tertentu. Perkembangan anak yang dicapai merupakan integrasi aspek pemahaman nilai-nilai agama dan moral, fisik, kognitif, bahasa dan sosial-emosional. ${ }^{13}$

Menurut Mukhtar Latif ada beberapa prinsip yang berkaitan dengan perkembangan anak, di antaranya: ${ }^{14}$

Pada dasarnya, prinsip perkembangan anak sebagai berikut:

1. Anak akan belajar dengan baik apabila kebutuhan fisiknya terpenuhi serta merasa aman dan nyaman dalam lingkungannya. 2009, h. 20

13 Permen Diknas No. 58 tahun

14 Mukhtar Latif, dkk, Orientasi Baru Pendidikan Anak Usia Dini: Teori dan Aplikasi, (Jakarta, Kencana: 2013), h. $72-73$
2. Anak belajar terus menerus, dimulai dari membangun pemahaman tentang sesuatu, mengeksplorasi lingkungan, menemukan kembali suatu konsep.

3. Anak belajar melalui interaksi sosial, baik dengan orang dewasa maupun dengan teman sebaya.

4. Minat dan ketekunan anak akan memotivasi belajar anak.

5. Perkembangan dan gaya belajar anak harus dipertimbangkan sebagai perbedaan individu.

6. Anak belajar dari hal-hal yang sederhana sampai yang kompleks, dari yang kongkret sampai ke yang abstrak, dari yang berupa gerakan ke bahasa verbal dan dari diri sendiri ke interaksi dengan orang lain.

\section{Pentingnya Pengenalan Perpus- takaan Sejak Dini}

Memperkenalkan perpustakaan sebagai salah satu "sarana informasi" yang merupakan kebutuhan mutlak masyarakat dalam era informasi perlu dilakukan. Kesadaran akan pentingnya perpustakaan ini memang sebaiknya dipupuk sejak kecil, oleh karena itu hal yang perlu dilakukan adalah menyediakan fasilitas yang memadai/baik untuk perpustakaan anak-anak. Akan tetapi sebelum melangkah ke arah itu, harus pula dipahami jiwa anak-anak tersebut dan informasi yang seperti apa yang dibutuhkan oleh anak-anak.

Secara umum, masa anak-anak merupakan masa awal dari suatu proses pencarian diri manusia. Oleh 
karena itu dunia anak-anak adalah dunia yang penuh petualangan, penuh dengan pertanyaan-pertanyaan, dan keinginan-keinginan yang belum tentu dapat kita jawab dan kita penuhi seluruhnya.

Ini menunjukan bahwa dunia itu ada suatu kebutuhan mutlak dari anak yaitu pengetahuan tentang dunia sekitar. Alat bantu utama untuk mencari pengetahuan ini adalah bukubuku. Dengan buku inilah anak-anak, seperti layaknya manusia dewasa pada umunya dibantu untuk memahami dunia sekitar. Pengetahuan yang diperoleh dari proses membaca ini akan menjadi bekal mereka dimasa yang akan datang. Tugas kita adalah mengajak, mengarahkan serta memberi contoh pada mereka untuk membaca dan membaca.

Pengenalan perpustakaan ini cukup penting, karena pada dasarnya sumber ilmu atau buku tersebut banyak terdapat di perpsustakaan. Agar sejak dini mereka mengetahui akan pentingnya perpustakaan yang dapat dijadikan sebagai sarana untuk mendapatkan ilmu dan informasi. Dengan memperkenalkan perpustakaan kepada anak usia dini, maka ketika mereka sudah dewasa nanti mereka akan mengetahui akan pentingnya perpustakaan yang merupakan salah satu tempat sumber pengetahuan bagi mereka.

Salah satu sumber belajar di sekolah adalah perpustakaan. Perpustakaan merupakan salah satu bagian yang sangat penting dari program sekolah secara keseluruhan. Perpustakaan sebagai gudang informasi dan ilmu pengetahuan yang menjadi sumber belajar yang digunakan oleh guru, dosen, siswa dan mahasiswa serta masyarakat dalam pelaksanaan pembelajaran. Terlebih pada era menyiratkan perlunya meningkatkan peran perpustakaan sekolah sebagai penunjang kegiatan pembelajaran.

Semua sependapat bahwa perpustakaan merupakan barometer kemajuan suatu bangsa, artinya maju atau mundurnya suatu bangsa dapat dilihat dari perpustakaannya, karena perpustakaan merupakan salah satu pranata sosial yang diciptakan oleh masyarakat dan dipelihara oleh masyarakat. Konsep yang menganggap bahwa perpustakaan sama dengan gudang buku yang tugasnya hanya untuk mengumpulkan, merawat dan menyediakan buku harus sudah ditinggalkan jika ingin mengikuti irama perkembangan ilmu pengetahuan. Namun, perpustakaan tidak hanya berkaitan dengan gudang buku saja, tetapi juga sistem penyimpanan, pemeliharaan dan pemustaka selaku pengguna. Langkah sejarah telah membawa perpustakaan memasuki Educational and Research Function dengan konsep baru yang mengangkat perpustakaan pada kedudukan yang terhormat, yaitu sebagai pusat kegiatan pendidikan dan aktifitas ilmiah.

Peranan perpustakaan dalam meningkatkan ilmu pengetahuan dan pendidikan masyarakat sangatlah penting dan besar. Hal ini tentu dikarenakan perpustakaan merupakan unit lembaga yang memberikan suatu pelayanan publik berupa penyediaan bahan-bahan pustaka. Undang-undang Republik Indonesia No. 43 tahun 2007 tentang Perpustakaan secara garis 
besar menyebutkan bahwa perpustakaan merupakan sebuah institusi yang mengelola koleksi karya cipta manusia yang berguna untuk memenuhi kebutuhan pendidikan, penelitian, pelestarian, informasi dan rekreasi para pengguna perpustakaan. Bagi civitas akademik, perpustakaan merupakan hal yang sangat vital dalam mencari informasi lebih-lebih dokumen sejarah berupa buku. Bagi para mahasiswa. Perpustakaan sangat membantu mereka dalam mengerjakan tugas kuliah dan mencari serta mengumpulkan informasi-informasi ilmu pengetahuan terbaru. Menimbulkan daya tarik membaca yang menarik itu, tidak bisa diperoleh secaa spontan. Karenanya, perlu strategi yang matang untuk menanamkan minat baca, salah satunya pengenalan perpustakaan kepada anak usia dini.

Tujuan perpustakaan pada dasarnya adalah sebagai wahana informasi yang dibutuhkan oleh dosen, guru, siswa, dan mahasiswa serta karyawan dan masyarakat pada umumnya sehingga proses penyebaran informasi dapat berjalan dengan baik. Sehingga penyelenggaraan perpustakaan bukanlah hanya untuk mengumpulkan dan menyimpan bahan-bahan pustaka saja, melainkan diharapkan mampu membantu mereka utamanya para pengajar dalam melaksanakan kegiatan belajar mengajar, sehingga tujuan pembelajaran serta kompetensi yang harus dimiliki oleh peserta didik dapat tercapai dengan lebih mudah.

Sebab, menumbuhkan minat baca masyarakat, harus dimulai sejak usia dini. Salah satu cara yang dapat dilakukan dengan cara mengenalkan anak-anak yang masih dini dengan buku-buku bacaan di perpustakaan.

Harapannya, dengan memperkenalkan perpustakaan, diharapkan minat baca anak menjadi lebih baik dan anak belajar mencintai buku.

\section{Dampak yang timbul jika anak tidak mengenal perpustakaan}

Masalah kurangnya perhatian terhadap pengenalan perpustakaan kepada anak usia dini sampai saat ini masih menjadi tema yang cukup menarik untuk dibahas. Tema ini sering dijadikan topik pertemuan ilmiah dan diskusi oleh para pemerhati dan para pakar yang peduli terhadap perkembangan minat baca di Indonesia. Namun hasil dari pertemuan-pertemuan ilmiah tersebut belum memberikan suatu rekomendasi yang tepat bagi perkembangan yang signifikan terhadap minat baca masyarakat. Permasalahan yang dirasakan oleh bangsa Indonesia sampai saat ini adalah adanya data berdasarkan temuan penelitian dan pengamatan yang menunjukkan bahwa minat baca masyarakat Indonesia relatif masih sangat rendah. Ada beberapa indikator yang menunjukkan masih rendahnya minat baca masyarakat Indonesia.

Bagi masyaraakat yang ada di pedesaan, pengenalan perpustakaan kepada anak usia dini jarang dijalankan secara optimal oleh pendamping anak usia dini, baik guru, orangtua dan lingkungan. Selain karena faktor lingkungan, juga sarana dan prasarana untuk penunjang tersebut tidak memadai. 
Sementara di perkotaan, minat para siswa terhadap perpustakaan cukup meningkat, perhatian pemerintah terhadap pengembangan perpustakaan di sekolah pun semakin besar. Dari sisi regulasi pemerintah telah megeluarkan beberapa peraturan yang memungkinkan perpustakaan di sekolah dapat berkembang dengan baik. Salah satu contoh dalam UndangUndang No. 43 tahun 2007 tentang perpustakaan. ${ }^{15}$ Tentu itu belum menjamin bahwa anak-anak akan bisa membaca dengan baik dan benar sesuai umurnya.

Ada beberapa faktor yang mempengaruhi rendahnya minat membaca pada anak: Pertama, masih rendahnya kemahiran membaca siswa di sekolah. Hasil penelitian yang dilakukan Tim Program of International Student Assessment (PISA) Badan Penelitian dan Pengembangan Depdiknas menunjukkan kemahiran membaca anak usia 15 tahun di Indonesia sangat memprihatinkan. Sekitar 37,6 persen hanya bisa membaca tanpa bisa menangkap maknanya dan 24,8 persen hanya bisa mengaitkan teks yang dibaca dengan satu informasi pengetahuan.

Kedua, sistem pembelajaran di Indonesia belum membuat anak anak/siswa/mahasiswa harus membaca buku (lebih banyak lebih baik), mencari informasi/pengetahuan lebih dari apa yang diajarkan, mengapresiasi

\footnotetext{
15 Undang-Undang No. 23 tahun 2007, Tentang Perpustakaan, h. 14-15
}

karya-karya ilmiah, filsafat, sastra dsb. ${ }^{16}$

Sebagai contoh siswa hafal salah satu panglima perang Pangeran Diponegoro adalah Sentot Alibasyah Prawirodirjo.Siswa tidak terdorong lebih lanjut untuk mengetahui bahwa Sentot masih berusia 18 tahun tatkala ketika memimpin pasukan berkuda.Dia berhasil menyergap kavaleri Belanda di sungai Bogowonto karena hidung kudanya diberi garam. Hal tersebut tidak akan ditanyakan di ujian, jadi tidak ada gunanya membaca lebih lanjut. Hal tersebut masih diperparah dengan buruknya perpustakaan sekolah, tiadanya jam kunjung ke perpustakaan serta buruknya perpustakaan umum yang seharusnya menunjang perpustakaan sekolah. ${ }^{17}$

Ketiga, banyaknya jenis hiburan, permainan (game) dan tayangan TV yang mengalihkan perhatian anak-anak dan orang dewasa dari buku. Berdasarkan temuan suatu penelitian, menunjukkan bahwa waktu bermain anak-anak Indonesia banyak dihabiskan untuk melihat acara acara di TV. Bandingkan dengan di AS, jumlah jam bermain anak-anak antara 3-4 jam per hari. Bahkan di Korea dan Vietnam, jam bermain anak-anak sehari hanya satu jam. Selebihnya anak-anak menghabiskan waktu untuk belajar atau membaca buku, sehingga tidak heran budaya baca sudah demikian tinggi. ${ }^{18}$

\footnotetext{
16 Shofaussamawati, Jurnal Perpustakaan Libsraria, (STAIN Kudus, 2014), Volume 2 Nomor 1, h. 53

${ }^{17}$ Ibid

${ }^{18}$ Ibid, h. 54
} 
Keempat, banyaknya tempat hiburan yang menghabiskan waktu seperti taman rekreasi, tempat karaoke, night club, mall, supermarket, play station. Di negeri kita, yang sebagian besar waktunya dihabiskan untuk menonton sinetron, membaca masih merupakan sesuatu yang eksklusif. Oleh karena itu, tidak perlu heran jika pemandangan di mall lebih rame ketimbang di perpustakaan.Acara musik lebih digandrungi dari pada acara diskusi, bedah buku atau seminar.Jangan kaget, jika kawula muda di negeri kita lebih banyak bercita-cita menjadi selebritis ketimbang bintang olimpiade sains.

Kelima, adalah faktor eksternal, di antaranya berhubungan dengan tingkat daya beli masyarakat yang rendah. Hal ini karena masyarakat pada umumnya berpenghasilan rendah. Angka kemiskinan memang telah berkurang tetapi pengurangan ini belum mencerminkan tingginya minat membaca. Kondisi perbukuan di Indonesia belum banyak mengundang minat membaca. Secara kuantitas buku bacaan yang tersedia belum memenuhi kebutuhan penduduk Indonesia. Produksi buku pelajaran baru mencapai sekitar 40 juta buku per tahun. Suatu jumlah yang sedikit bila dibandingkan dengan Negara-negara lain yang mampu memproduksi lebih banyak per tahun. ${ }^{19}$

Dalam Undang-Undang Nomor 23 tahun 2003 tentang Sistem Pendidikan Nasional, pada pasal 45 disebutkan bahwa setiap satuan pendidikan formal dan nonformal menyediakan sarana dan prasarana yang memenuhui keperluan pendidikan

\section{${ }^{19}$ Ibid}

sesuai dengan pertumbuhan dan perkembangan potensi fisik, kecerdasan intelektual, sosial, emosional dan kewajiban peserta didik. Saran dan prasarana yang dimaksud dalam Undang-Undang tersebut di antaranya penyediaan perpustakaan di sekolah. $^{20}$

Di dalam pasal 3 UndangUndang Nomor 43 tahun 2007 disebutkan bahwa: "Perpustakaan berfungsi sebagai wahana pendidikan, penelitian, pelestarian, informasi, dan rekreasi untuk meningkatkan kecerdasan dan keberdayaan bangsa."21 Fungsi pendidikan diwujudkan dengan perpustakaan yang mampu meningkatkan kegemaran membaca penggunanya. Fungsi penelitian diterapkan dengan menyediakan pelayanan untuk pemakai dalam memperoleh informasi sebagai bahan rujukan untuk kepentingan penelitian. Fungsi pelestarian yaitu sebagai tempat melestarikan bahan pustaka (bahan pustaka merupakan sumber ilmu pengetahuan, teknologi, dan budaya). Fungsi informasi diterapkan dengan menyediakan sumber-sumber pustaka yang lengkap dan bermutu. Fungsi rekreasi diterapkan dengan menyediakan buku hiburan dan tata ruang yang bersifat rekreatif.

Lebih lanjut, pada Pasal 4 disebutkan juga "Perpustakaan bertujuan memberikan layanan kepada pemustaka, meningkatkan kegemaran membaca, serta memperluas wawasan

20 Yaya Suhendar, Panduan Petugas Perpustakaan Cara Mengelola Perpustakaan Sekolah Dasar, (Jakarta, Prenada: 2014), h. 1-2

${ }^{21}$ Undang-Undang No. 23 tahun 2007, op. Cit, h. 4 
dan pengetahuan untuk mencerdaskan kehidupan bangsa."22

\section{PENUTUP}

Kata perpustakaan berasal dari kata pustaka, yang berarti kitab , bukubuku, kitab primbon. Kemudian kata pustaka mendapat awalan per dan akhiran an, menjadi perpustakaan. Perpustakaan mengandung arti: kumpulan buku-buku bacaan, bibliotek dan hukum-hukum kesusastraan.

Selanjutnya ada istilah "pustakalokal" yang berarti tempat atau ruangan perpustakaan. Pengertian yang lebih umum dan luas dari perpustakaan adalah suatu ruangan, bagian dari gedung/bangunan, atau gedung itu sendiri, yang berisi bukubuku koleksi, yang disusun dan diatur demikian rupa sehingga mudah untuk dicari dan dipergunakan apabila sewaktu-waktu diperlukan oleh pembaca. Perpustakaan dilengkapi dengan berbagai sarana dan prasarana, seperti ruang baca, rak buku, rak majalah, meja kursi, baca kartu-kartu katalog, sistem pengelolaan tertentu dan ditempatkan petugas yang menjalankan perpustakaan agar dapat berjalan sebagaimana semestinya.

Memperkenalkan perpustakaan sebagai salah satu "sarana informasi" yang merupakan kebutuhan mutlak masyarakat dalam era informasi perlu dilakukan. Kesadaran akan pentingnya perpustakaan ini memang sebaiknya dipupuk sejak kecil, oleh karena itu hal yang perlu dilakukan adalah menyediakan fasilitas yang memadai/baik untuk perpustakaan anak-anak. Akan tetapi sebelum

$$
{ }^{22} \text { Ibid }
$$

melangkah ke arah itu, harus pula dipahami jiwa anak-anak tersebut dan informasi yang seperti apa yang dibutuhkan oleh anak-anak.

Secara umum, masa anak-anak merupakan masa awal dari suatu proses pencarian diri manusia. Oleh karena itu dunia anak-anak adalah dunia yang penuh petualangan, penuh dengan pertanyaan-pertanyaan, dan keinginan-keinginan yang belum tentu dapat kita jawab dan kita penuhi seluruhnya.

Pengenalan perpustakaan ini cukup penting, karena pada dasarnya sumber ilmu atau buku tersebut banyak terdapat di perpsustakaan. Agar sejak dini mereka mengetahui akan pentingnya perpustakaan yang dapat dijadikan sebagai sarana untuk mendapatkan ilmu dan informasi. Dengan memperkenalkan perpustakaan kepada anak usia dini, maka ketika mereka sudah dewasa nanti mereka akan mengetahui akan pentingnya perpustakaan yang merupakan salah satu tempat sumber pengetahuan bagi mereka.

Masalah kurangnya perhatian terhadap pengenalan perpustakaan kepada anak usia dini sampai saat ini masih menjadi tema yang cukup menarik untuk dibahas. Tema ini sering dijadikan topik pertemuan ilmiah dan diskusi oleh para pemerhati dan para pakar yang peduli terhadap perkembangan minat baca di Indonesia. Namun hasil dari pertemuan-pertemuan ilmiah tersebut belum memberikan suatu rekomendasi yang tepat bagi perkembangan yang signifikan terhadap minat baca masyarakat. Permasalahan yang dirasakan oleh bangsa Indonesia 
sampai saat ini adalah adanya data berdasarkan temuan penelitian dan pengamatan yang menunjukkan bahwa minat baca masyarakat Indonesia relatif masih sangat rendah. Ada beberapa indikator yang menunjukkan masih rendahnya minat baca masyarakat Indonesia.

Bagi masyaraakat yang ada di pedesaan, pengenalan perpustakaan kepada anak usia dini jarang dijalankan secara optimal oleh pendamping anak usia dini, baik guru, orangtua dan lingkungan. Selain karena faktor lingkungan, juga sarana dan prasarana untuk penunjang tersebut tidak memadai.

Sementara di perkotaan, minat para siswa terhadap perpustakaan cukup meningkat, perhatian pemerintah terhadap pengembangan perpustakaan di sekolah pun semakin besar. Dari sisi regulasi pemerintah telah megeluarkan beberapa peraturan yang memungkinkan perpustakaan di sekolah dapat berkembang dengan baik. Salah satu contoh dikeluarkannya Undang-Undang No. 43 tahun 2007 tentang perpustakaan.

Bagi masyaraakat yang ada di pedesaan, pengenalan perpustakaan kepada anak usia dini jarang dijalankan secara optimal oleh pendamping anak usia dini, baik guru, orangtua dan lingkungan. Selain karena faktor lingkungan, juga sarana dan prasarana untuk penunjang tersebut tidak memadai.

Sementara di perkotaan, minat para siswa terhadap perpustakaan cukup meningkat, perhatian pemerintah terhadap pengembangan perpustakaan di sekolah pun semakin besar. Dari sisi regulasi pemerintah telah megeluarkan beberapa peraturan yang memungkinkan perpustakaan di sekolah dapat berkembang dengan baik. Salah satu contoh dalam UndangUndang No. 43 tahun 2007 tentang perpustakaan. ${ }^{23}$ Tentu itu belum menjamin bahwa anak-anak akan bisa membaca dengan baik dan benar sesuai umurnya.

Ada beberapa faktor yang mempengaruhi rendahnya minat membaca pada anak: Pertama, masih rendahnya kemahiran membaca siswa di sekolah. Hasil penelitian yang dilakukan Tim Program of International Student Assessment (PISA) Badan Penelitian dan Pengembangan Depdiknas menunjukkan kemahiran membaca anak usia 15 tahun di Indonesia sangat memprihatinkan. Sekitar 37,6 persen hanya bisa membaca tanpa bisa menangkap maknanya dan 24,8 persen hanya bisa mengaitkan teks yang dibaca dengan satu informasi pengetahuan.

Kedua, sistem pembelajaran di Indonesia belum membuat anak anak/siswa/mahasiswa harus membaca buku (lebih banyak lebih baik), mencari informasi/pengetahuan lebih dari apa yang diajarkan, mengapresiasi karya-karya ilmiah, filsafat, sastra dsb.

Ketiga, banyaknya jenis hiburan, permainan (game) dan tayangan TV yang mengalihkan perhatian anak-anak dan orang dewasa dari buku.Berdasarkan temuan suatu penelitian, menunjukkan bahwa waktu bermain anak-anak Indonesia banyak

23 Undang-Undang No. 23 tahun 2007, Tentang Perpustakaan, h. 14-15 
dihabiskan untuk melihat acara acara di TV. Bandingkan dengan di AS, jumlah jam bermain anak-anak antara 3-4 jam per hari. Bahkan di Korea dan Vietnam, jam bermain anak-anak sehari hanya satu jam. Selebihnya anak-anak menghabiskan waktu untuk belajar atau membaca buku, sehingga tidak heran budaya baca sudah demikian tinggi.

Keempat, banyaknya tempat hiburan yang menghabiskan waktu seperti taman rekreasi, tempat karaoke, night club, mall, supermarket, play station. Di negeri kita, yang sebagian besar waktunya dihabiskan untuk menonton sinetron, membaca masih merupakan sesuatu yang eksklusif. Oleh karena itu, tidak perlu heran jika pemandangan di mall lebih rame ketimbang di perpustakaan.Acara musik lebih digandrungi dari pada acara diskusi, bedah buku atau seminar.Jangan kaget, jika kawula muda di negeri kita lebih banyak bercita-cita menjadi selebritis ketimbang bintang olimpiade sains.

Kelima, adalah faktor eksternal, di antaranya berhubungan dengan tingkat daya beli masyarakat yang rendah. Hal ini karena masyarakat pada umumnya berpenghasilan rendah. Angka kemiskinan memang telah berkurang tetapi pengurangan ini belum mencerminkan tingginya minat membaca.

\section{DAFTAR KEPUSTAKAAN}

Bafadal, Ibrahim, Pengelolaan Perpustakaan Sekolah, (Jakarta, Bumi Aksara: 2011)
Kamus Besar Bahasa Indonesia-KBBI, (Jakarta, Kencana: 1988)

Latif, Mukhtar, dkk, Orientasi Baru Pendidikan Anak Usia Dini: Teori dan Aplikasi, (Jakarta, Kencana: 2013)

M. Yusuf, Pawit, Pedoman Penyelenggaraan Perpustakaan Sekolah, (Jakarta, Kencana: 2005)

Permen Diknas No. 58 tahun 2009, h. 20

Rifai, Agus, Perpustakaan Islam: Konsep, Sejarah, dan Kontribusinya dalam Membangun Peradaban Islam Masa Klasik, (Jakarta, Rajawali Pers: 2013)

Shofaussamawati, Jurnal Perpustakaan Libsraria, (STAIN Kudus, 2014), Volume 2 Nomor 1

Suhendar, Yaya, Panduan Petugas Perpustakaan Cara Mengelola Perpustakaan Sekolah Dasar, (Jakarta, Prenada: 2014)

Sutarno NS, Perpustakaan dan Masyarakat, (Jakarta, Yayasan Obor Indonesia: 2003)

Undang-Undang No. 23 tahun 2007, Tentang Perpustakaan

http://warintek08.wordpress.com/tes/, http://kbbi.web.id/pustaka, 